Arab World English Journal (AWEJ) 2 $2^{\text {nd }}$ Special Issue on Covid 19 Challenges January 2022 DOI: https://dx.doi.org/10.24093/awej/covid2.5

\title{
Exploring Teachers and Students' Perceptions towards Emergency Online Learning Intensive English Writing Course during COVID-19 Pandemic
}

\author{
Hebah Asaad Hamza Sheerah \\ English Department, Applied College for Girls \\ King Khalid University, Abha, Saudi Arabia \\ Corresponding Author: hsheerah@kku.edu.sa \\ Meenakshi Sharma Yadav \\ English Department, Applied College for Girls \\ King Khalid University, Abha, Saudi Arabia \\ May Ali Elzein Fadl Allah \\ English Department, Applied College for Girls \\ King Khalid University, Abha, Saudi Arabia \\ Ghazwa Jalal Abdin \\ English Department, Applied College for Girls \\ King Khalid University, Abha, Saudi Arabia
}

Received: 9/2/2021

Accepted:10/28/2021

Published: 1/24/2022

\begin{abstract}
For ages, teaching and learning face-to-face has been very popular and considered the best way to achieve knowledge and accomplish academic activities. However, during the Covid-19 Pandemic, where on the one side, the whole world was searching for a solution to cope with the situation on the other side online learning demonstrated a substantial alternative. The present paper aimed to investigate the teachers and students' perceptions of the emergency online learning process, especially for intensive English writing courses. The study is descriptive using the qualitative research methodology. The two focus groups (teacher and student) are interviewed, consisting of 42 participants, asking open-ended questions mainly about the benefits and challenges of the writing course during the Pandemic. The paper ends with the teachers and students' positive response that indicates the thrilled and jubilant welcome of the synchronized online/virtual learning in the latest situation that emerged due to the Pandemic. Eventually, the study discussed the quality assurance efforts, particularly towards the spontaneous conduction of lectures infused with motivation, responsibility, discipline, and flexibility offered without any interruption. The Internet proved a great learning tool in assuring many resources.
\end{abstract}

Keywords: COVID-19 Pandemic, IEP, ELL, online learning, process approach, students' perception, Saudi context, teachers' perception, virtual classes, writing skills

Cite as: Sheerah, H. A. H., Yadav, M. S., Allah, M. A.E.F., \& Abdin, G. J. (2022). Exploring Teachers and Students' Perceptions towards Emergency Online Learning Intensive English Writing Course during COVID-19 Pandemic . Arab World English Journal (AWEJ) $2^{\text {nd }}$ Special Issue on Covid 19 Challenges

(2) 64-84 DOI: https://dx.doi.org/10.24093/awej/covid2.5 


\section{Introduction}

Decades of research have focused on teaching and learning English skills and their domains to second language learners. However, when it comes to writing skills, it always becomes subject to erroneous structure and productivities. In addition, writing is an influential medium of communication that English second language learners (ESLL) require it to master expressing their feelings, concepts, and opinions innovatively. Consequently, there has been a long-standing interest in learning writing skills utilizing the resources provided in a traditional classroom in the instructor's presence.

Undoubtedly, several studies have also shown that e-learning technologies (blended/virtual) have become widespread and well-known among students to learn a second language collaboratively and subjectively. Moreover, the sudden eruption of the pandemic made virtual learning comprehensive using the electronic gateway. However, overall, it remains unclear how much students have been helped and benefited from this support and assistance provided by the whole e-Learning platform.

Instructors and students were hesitant to use virtual classes on the comprehensive eLearning platform since they were accustomed to traditional classes. However, a few courses were delivered through the blended medium. The instructors and students were trained well through the university e-Learning units and tools as a standard-trend orientation starting the academic session every year. However, since the Pandemic has forced everyone to attend online classes, they had no other options for their academic accomplishments. Consequently, instructors and students started to be present on the virtual platform, and they could succeed to manage their courses to the pedagogy and enhancement. It pushed them into a new-normal situation as before they used to entertain and productive the teaching and learning of the courses. For example, when students write different writing drafts in the online portal for online writing skills enhancement, their instructors and peers check and develop the drafts and give them quick feedback. E-platform loaded software also reveal plagiarism and grammatical errors in these written writing pieces by students most adequately. Thus, the new-normal situation prepared everyone to utilize online platforms to teach and learn the academic courses.

Another hand, Pandemic pushed us in the virtual revolution and challenged the latest standard physical infrastructures and organizations worldwide. It created new domains for every aspects of personal and professional needs. Social media users at all generations are most of the world's population have been produced as members of the e-world. Now learners and professionals from the remote corners of the words can virtually meet and see simultaneously on a single platform. It diminished all the discriminative issues of caste, colour, creed, the danger of gender and so on; it brought them together on the virtual reception of the oneness. Learners and institutions can be benefitted from the most efficient and profession certified instructors online from any country at the same time. In the future, if any epidemics emerge, the online platform will be helpful with more advanced technologies at all times. Therefore, any epidemics will never affect their pedagogy and enhancement of the courses on the single reception of the online platform across the world.

This present article aimed to discover the teachers and students' perceptions of the emergence of online learning of IEP in particular writing skills. Despite the importance of 
Arab World English Journal (AWEJ) 2nd Special Issue on Covid 19 Challenges January 2022

enhancing the writing skills using the online platform, the study investigated the challenges and suggestions in a unique premise.

\section{Literature Review}

\section{A. Covid-19 Pandemic and Online Teaching-Learning Pedagogy and Enhancement -}

The ghastly novel coronavirus, Covid-19, one of the world's deadliest viruses ever unprecedented global health crises to all the aspects of life disproportionately (Remuzzi \& Remuzzi, 2020) and resulted in an immediate nationwide lockdown, keeping all the world indoors. This Pandemic brought the most unexpected disturbing, and devastating things (Schulten, 2020) in the panorama of education pedagogy and enhancement process worldwide since the beginning of 2020 (Mishra et al., 2020; Martinez, 2020). On account of the existing situations and circumstances, Saudi Ministry also implemented all the preventive and precautionary measures beforehand. The Saudi Ministry of Education (MOE) directed that virtual schools and distance education will be active. In contrast, the schools are closed to ensure that the educational process continues in an effective and quality manner (Arab News, March 2020). Therefore, the traditional \& on-campus classes at the academic institutions were suspended on the massive closure to prevent the virus's spread and mitigate its impact globally (Rieley, 2020; Dhawan, 2020). As a result, regular students of all ages shifted to their online classes at their homes, and along with attendance suspension, distance education was enforced on the same date (Arab News, March 2020). Besides, direct instructional classes were shifted to teaching online for an indefinite time as the only option left (Martinez, 2020) before educational institutions from kindergarten to the tertiary level (EdSource, 2020). Moreover, a massive challenge triggered how education procedures could continue before the whole world's education systems (Daniel, 2020).

Consequently, the current teaching pedagogy and methodology were adversely affected; hence the new tech-pedagogical approaches were developed and produced to make successful the objectives of the online teaching-learning process across the world (Mishra et al., 2020). A few organizations had their online learning management systems (LMS), blackboards, eLearning units, and other smart digital resources (Usko et al., 2019), but most educational organizations in the world did not have such resources; therefore, their educational activities collapsed completely (Dhawan, 2020). As a result, they shifted their education process to easy and popular online communication platforms that changed the destination and direction of the whole education system from group to stay-at-home, from personal to virtual, from seminars to webinars, and from classrooms (Mishra et al., 2020) to LMS, Blackboard, Google Meet, Google Classroom, Zoom, WhatsApp, Facebook, Messenger, DTH and many more channels across the world.

The advanced technological electronic handy-gadgets like smartphones, tablets, laptops, computers, projectors with the connectivity of the Internet has made online education accessible, mobile, and flexible (Yadav, 2020), and this technology for instruction has become an integral part of successful teaching (Almaiah et al., 2020; Ferri et al., 2020). Moreover, these tools enabled communication and facilitated the learners synchronously at the 'same time - different place' mode (Khalil \& Ebner, 2017). This synchronous communication method made live interactions, spontaneous reactions, and immediate feedback between the instructors and the students through audio-video conferencing and web-chats (Rapanta et al., 2020). Simultaneously, 
Arab World English Journal (AWEJ) 2nd Special Issue on Covid 19 Challenges January 2022

the asynchronous mode of communication made learners interconnected and collaborative over time through a 'different time - different place' mode, e.g., audio recordings, emails, vodcasts, lectures, discussion forums (Khalil et al., 2020).

The conduction of virtual classes proved a boon for education enhancement as the teaching and learning practice did not hinder even a single day in the Kingdom throughout the Pandemic (Hassounah et al., 2020). Saudi Arabia was one of the fastest countries to respond to educational emergencies, and its efforts were tremendous (Lily et al., 2020). Hassounah et al. (2020) mentioned that-

E-Learning is not new in the Kingdom. In 2017, as part of Vision 2030, the Ministry of Education established the National Center for e-Learning. This center serves to supervise and support e-Learning in Saudi Arabia. However, the COVID-19 situation challenged the higher educational institutions to continue tutoring and assessing technical skills. Hence, universities offered different methods of e-learning support depending on the course requirements and interim assessment needs (p.37).

To ensure full technical support and assistance in the learners' journey as a real-like environment in distance education, different virtual classroom technologies, distance education platforms, and e-portals were incorporated to facilitate the learning process at ascending levels (Ionescu et al., 2020). Furthermore, through the electronic gateway (Tejedor et al., 2020), virtual learning has proven to be a proliferation in imparting instructions, lectures, training, presentations, guidelines, didactic messages, and audio-video clips to positively educate and prepare all participants to receive and interact actively. This innovative way of teaching and learning enhanced learners' ability to deal with technology and think creatively and critically to solve the problems at hand individually (Serdyukov, 2017). Besides, it accepted learners to be more personalized, collaborated and better linked between formal and informal learning.

\section{B. Online Teaching-Learning of IEP Language Skills-}

From the preliminary days of the Internet, online learners and instructors have looked for ways to use it as a resource for teaching and learning language skills. However, despite the interest, teaching language skills online is as tricky as learning them (Lynch, 2020). Pondering over the latest results of online learning, it collaborated and facilitated the language learners in learning the language skills (Ali, 2017); yet, it showed that learning the productive skills (speaking and writing) did not reflect a good impression on the learners fully (Karata \& Tuncer, 2020). Investigating students' perceptions of Blackboard as an online learning tool in the era of Covid-19 showed that their perceptions toward online learning was not favorable (Al-Nofaie, 2020). However, the perceptions of 1st level students towards the Blackboard tool for English Language courses and skills were more positive than the 2 nd level students. They concluded that although Blackboard helped students improve their listening skills, but not sure of writing and speaking skills (Almekhlafy, 2020). Alhujaylan (2019) revealed CALL's efficacy in improving writing skills with innovative techniques and robust, long-lasting learning strategies. Nevertheless, the transition from traditional classroom/face-to-face learning to exclusive online or blended learning is not without diverse challenges (Mpungose, 2020). 
Arab World English Journal (AWEJ) 2nd Special Issue on Covid 19 Challenges January 2022

Exploring Teachers and Students' Perceptions

Sheerah, Yadav, Allah, \& Abdin

\section{Research Studies on IEP Academic Writing Skills-}

EFL students in the KSA are a thought-provoking pursuit who are not proficient in language skills mainly due to exposure to English in elementary education. In addition, the influence of L1 on the target language, lack of practical use in everyday life, cultural issues and attitude concerning learning English (Basabrin 2019; Mansory 2019), lack of motivation, and learning environment outside the classroom are other reasons. Numerous previous studies considered that low English linguistic proficiency and limited attainment of language skills is a frequently encountered problem for EFL learners in the Saudi context, whereby their level of proficiency remains below expectations (Belabes, 2018; Khan, 2020). As a result, EFL learners face many problems that negatively affect their mastering of English skills (Sadighi \& Dastpak,2017).

Academic writing is a productive and indispensable skill among the four skills (LSRW) to be learned, but on the contrary, it is the most challenging and complex to be mastered by ESL/EFL learners. The phenomenon of Second Language Writing defines as writing done in a language other than the writer's native language(s)/mother tongue(s), and texts are orderly arrangements of words, clauses, and sentences, following grammatical rules in an organized way. Therefore, academic writing is a tool for language learning and assessing learners' competence in a language (Ana, 2020; McDonough \& Crawford, 2020). Here students are supposed to compose an error-free paragraph, essay, report, academic paper, critical note, and answers in cohesion and coherence during the exam. (Yousuf 2019). Students should think critically and analytically, and therefore; it is worth noticing to persuade perfect mechanisms of writing a draft with suitable vocabulary, a coherent scientific flow of thoughts (Faradhibah \& Nur, 2017), and a clear and lucid structure followed by the body are conditions for students' academic success and effective written communication. In this way, academic and scholarly writing is nonfiction produced as part of academic work (Samuels, Boba; Garbati, Jordana, 2018). Moreover, it is needed to be reliable and relevant, supported by some evidence.

Saudi students do not feel confident composing a writing draft academically after studying for many years. They commit grammatical and spelling mistakes and find structural complications while texting academic writing (Alharbi, 2017). Saudi learners are likely to be very dependent on the modeled written texts, which in turn limited their freedom, creativity, and autonomy in writing, besides lack of exposure and practice was also one of the reasons that hindered the acquisition of the writing skill in Saudi Arabia (Almusharraf, 2019; Basabrin, 2019; Alrabai, 2017). Ashraf (2018) identified that the prescribed textbooks with minimal linguistics features fail to meet the learners' requirements. In an EFL situation, most of the students rely on memorizing rather than learning a language to pass the exam, i.e., remembering the writing answer(s)/paragraph(s) rather than the proper approaches to developing the most common writing strategies when writing an answer (Alzaidi, 2017).

In his research, Alharbi (2017) investigated that most EFL students do not follow the writing mechanism; have difficulty in making capitalization and punctuations, weakness in spelling and grammar, lower motivation, and inappropriate teaching methods, structural difficulties (Alharbi, 2019) therefore, not able to write topic sentences and supporting sentences. On the other hand, Bakkar (2019) and Alzamil (2019) found that EFL students are fragile in 
Arab World English Journal (AWEJ) 2nd Special Issue on Covid 19 Challenges January 2022

extended writing, such as descriptive, argumentative, narrative, expository, and unable to go beyond a paragraph level.

Some social factors and contexts of EL learning affect the learner's belief and attitude and shake the learner's motivation to learn. Cultural ignorance of the target language is also an obstacle to Saudi students as language and culture are two in each other's pockets (Al-Hattami, \& Al-Ahdal, 2020; Mutambik, 2018). Arab learners perceive writing in the traditional style, abiding by rules and a specific structure (Altheneyan \& Boayrid, 2019). Farooq et al. (2018) also found that culture plays a significant role when a learner learns English as a foreign language; it becomes essential to understand the target language's culture to express thoughts, ideas, and feelings copiously.

The influence of the mother tongue works as a major problem to learning English (Al Shahrani, 2018;); therefore, the writing errors refer to the interference of mother tongue, overgeneralization, insufficient activities and practice of basic writing techniques. (Ahmed, 2018; Hafiz, Omar \& Gul Sher 2018). In his study, Khan (2020) found that different curves, shapes, upper and lower case of English and Arabic alphabets, and letters look very awkward orthogonally to the Arabic EL learners. Furthermore, the Kingdom's elementary and secondary schools give less attention to punctuation; that is why it is common to find Arabic learners mixing capital and small letters within words and sentences, not using commas and full stops properly. Therefore, academic writing incapability generates due to the cultural and structural dissimilarities between Arabic and English. Khatter (2019) discussed that commas and conjunctions are also other difficulties for Arabic students because the usage is different in Arabic and English contexts.

\section{Online IEP Writing Skills: Advantages and Disadvantages-}

Although many instructors still consider teaching face-to-face is the best way to achieve knowledge, online learning demonstrates to be a substantial alternative during Covid-19. In the traditional classes, by focusing on the students or the student-centered principles, the students can develop their whole abilities, potential, achievement and behavior through meaningful and valuable activities with a new insight in enhancing their writing ability (Indrilla \& Ciptaningrum, 2018). However, the virtual environment has offered language learners several opportunities to improve their writing skills (Aghajani \& Adloo, 2018) and enhanced their learning capabilities using a new mode of writing using technology (Aguiar \& Pearsall, 2020). This immersive technology provides each user with active control and more authentic experiences, helping students learn more effectively and increasing their retention by combining visual, auditory, and kinesthetic learning styles (Radianti et al., 2020). Online learning makes learners self-paced who can review their resources and materials. This allows them to integrate more media (video, images, audio, etc.) and improve their activities multiple times (Rapanta et al., 2020). The students can use these resources and materials while composing any writing tasks. It is more flexible to monitor students' progress in online environments, and instructors can provide automated feedback. They also give students more opportunities to practice their writing. Moreover, the instructors can vary tasks for every student according to their level and learning styles. In addition, online environments can facilitate engagement in profound, meaningful ways (Rapanta et al.,2020). 
Students have the opportunity to study in their own time. Online learning is an effective way because students can do their homework quickly; through e-Learning tools, students of IEP might perform better (Putri et al. 2020; Kaden, 2020; Ijaz Hussain, Saeed \& Syed, 2020; Niittylahti, Annala, \& Mäkinen, 2021). In addition, the blackboard helps students to a great extent to write better by giving them some clues and recommendations for better writing (Al Tameemy, Alrefaee \& Alalwi, 2020).

There are such disadvantages of applying online writing skills for the students. They do not have the training to use the pen as the physical interaction between the instructor and the learners is absent in a virtual setting. Online writing instruction works well for many students, even better than traditional onsite learning, but not for all. Instructors are accustomed to interacting with college students to give quick feedback on the submitted work. However, this habit of giving instant feedback burdens teachers in online teaching. The writing assignment takes a maximum of 30 minutes to check, and teachers can provide, on average, 4-6 assignments per day. While in a face-to-face class setting, students can do formative assessments and feedback more quickly (Woodrich \& Fan, 2017; Putri et al., 2020). Online learning makes it teachers take longer to give feedback, especially for writing skills.

\section{E. Implementations in Online Writing Skills' Learning-}

Achieving better results and developing students' writing competence remains an arduous task for English teachers. However, research shows that different approaches are engaged in the ESL classroom, yet ESL teaching of writing implemented process approaches at different levels. Results also indicated that scaffolding cooperative learning and teacher-peer feedback helps to improve ESL students' writing skills (Melanie \& Azlina,2019).

Therefore, we need to give particular attention to the methodology and activities adopted in the virtual environment. Along with the technology and process, we need positive attitudes of teachers and students. (Aghajani \& Adloo, 2018; Gharehblagh \& Nasri, 2020; Alzankawi, 2017). The language instructors and students utilize writing materials that they restrict to the blackboard and the course book. That is why online learning might make teaching writing very interesting and provoke students to learn writing skills properly. The effectiveness of online graphic writing and the learners' positive attitudes showed that it helped them do digital revising and was entertaining (Kılıçkaya 2019). Bahari and Salimi (2021) found that generating automated written content and online written corrective feedback scored (21\%) is the most frequently reported affordance to write, and it indicates the significant improvement in writing. Instructors are the mediators between the technological tools and students during using online, and it does not confine with the use of educational technology. However, they are also responsible for students' specific needs in a virtual classroom, such as selecting and adapting online tools to meet IEP students' best needs (Purpura, Napoli, Wehrspann, \& Gold, 2017).

Al-Ghazi et al. (2018) figured out that social constructivist learning design had a significant role in promoting writing skills than the traditional way of teaching to the students. Therefore, instructions provided via online platforms can significantly improve students' interest and motivation for writing skillfully. The teacher can initiate contact via phone calls and informal online chats to compensate for face-to-face interaction. These chats can encourage spontaneous interactions between students themselves and teachers, which resulted in building 
positive relationships and the foundation for learning communities (Angelino, Williams \& Natvig, 2017), by chatting students try their best to write as accurate as possible to avoid spelling and grammatical mistakes, so indirectly they will learn writing skills. An instructor must provide content with a great degree of flexibility, encouraging a competitive spirit among the students. Writing exercises must be straightforward and familiar to students (Alfehaid, 2019).

The students also have some online learning responsibilities, such as they must participate in online courses regularly and effectively. Furthermore, they must manage the time, such as making self-reminders and doing the assignments accurately. Therefore, the student must pay great efforts to the course's schedule and deadlines attentively. In addition, they must attain all necessary course materials, such as textbooks, lab materials, and course software. Finally, the most important one is to check computer set up and internet connectivity (Tuma et al., 2021).

\section{F. A Comparison of the Standard Classroom and Online Writing Classes-}

With the emergence of Covid-19, online teaching-training has become extremely popular and necessary as it is the sole means of continuing the teaching and learning process, as several universities, schools, and institutes are offering their courses online. Simultaneously, despite the rising popularity of online courses, the standard classroom is still very attractive and fighting back and trying to adopt newer means of holding learners' interest.

\begin{tabular}{|l|l|}
\hline Online class & Standard classroom \\
\hline $\begin{array}{l}\text { Less interaction between students and } \\
\text { teachers; as for handwriting, students } \\
\text { might profoundly become dependent on } \\
\text { computer tools to direct them } \\
\text { (Muthuprasad, Aiswarya, Aditya, \& Jha, } \\
\text { 2021). }\end{array}$ & $\begin{array}{l}\text { Standard classes involve direct interaction } \\
\text { between the students and the teachers, } \\
\text { which help to make bond relationships. The } \\
\text { teacher can direct the students who are } \\
\text { weak in handwriting as it is easy to glance } \\
\text { at their weakness, holding the pen, the way } \\
\text { of writing that plays a significant role in } \\
\text { improving writing skills. (Honey, 2020) }\end{array}$ \\
\hline $\begin{array}{l}\text { Students who do not have enough } \\
\text { discipline may not achieve the required } \\
\text { level of education, especially in writing } \\
\text { skills. In addition, many students escape } \\
\text { from participating in its activities because } \\
\text { there is nobody to push them around. }\end{array}$ & $\begin{array}{l}\text { The disciplined students can be pushed and } \\
\text { motivated by their peers (Gelles et al., } \\
\text { 2020). In addition, they can learn from their } \\
\text { peer how to write correctly, as learning } \\
\text { English writing might differ from their } \\
\text { mother tongue writing system. }\end{array}$ \\
\hline $\begin{array}{l}\text { Students might miss such discussions, } \\
\text { talks, and explanations as to the lack of } \\
\text { direct interaction (Agung, Surtikanti \& } \\
\text { Quinones, 2020). }\end{array}$ & $\begin{array}{l}\text { Students have a great chance to ask } \\
\text { regarding a given course content which the } \\
\text { teacher can clarify. }\end{array}$ \\
\hline $\begin{array}{l}\text { Writing materials are provided with video } \\
\text { or audio texts, enabling the student to } \\
\text { watch as much as s/he wants. }\end{array}$ & $\begin{array}{l}\text { Students are rarely provided with the course } \\
\text { materials by their teacher. (Bergdahl \& } \\
\text { Nouri, 2020). As well as once practiced in } \\
\text { the class, rarely repeated. }\end{array}$ \\
\hline
\end{tabular}

\section{Study Questions}

1. What are EIP students and teachers' perceptions concerning the benefits of emergency of online learning on writing course during COVID-19 pandemic? 
2. What are EIP students and teachers' perceptions concerning the challenges of emergency of online learning on writing course during COVID-19 pandemic?

3. What are EIP students and teachers' suggestions on how online programs could be helpful to develop English language skills?

\section{Methods}

This study is a case study research. The researchers apply qualitative data collection to explore IEP students and teachers' perceptions regarding the usefulness of synchronized online learning during the pandemic at Community College for Girls, King Khalid University in Saudi Arabia. This study uses focus groups to benefit richer insights into research problems from diverse points of interpretation as the interviewees focus the discussion on a specific topic. In addition, a structured exploratory focus group gains more profound perceptions into the research problem throughout the communications between interviewees with different experiences by asking a few open-ended questions.

The target population was all female EFL undergraduates attending the Intensive English Program (IEP) at Community College for Girls at King Khalid University and EFL teachers who taught in this program across the university. Within this target population, a sample was selected that consisted of two groups of students, and two groups of teachers. Each group contained from five to eight EFL students from the university. The focus group interview data were gathered from 42 participants, Six teachers and 36 students. In this study, homogeneous purposive sampling was implemented with the sample of EFL students to gain a detailed understanding of the research problem.

This study employed a thematic analysis framework that encompasses major themes, subthemes, color coding accompanied with exact interviewees' quotes in the transcription. Braun and Clarke (2006) defined thematic analysis as 'a method for identifying, analyzing and reporting patterns within data' (p. 79).

\section{Data Collection Process}

Researchers contacted EFL teachers and EFL students via email to be interviewed online in the study focus group interviews. It was emphasized that their contribution was voluntary. The focus groups' interview guide included three themes with questions referring to EFL students and teachers' perceptions concerning the benefits, challenges, and recommendations for improving online learning skills in the preparatory year at the university.

During the focus group interview session, the purpose of the study was explained, and the essential to provide honest views to support the expansion of the trustworthiness of the study. The focus group interviews lasted between 1 and 2 hours. First, four brief open-ended questions were asked to get participants' thinking about the issues. The preliminary question was an icebreaker. Next, the core questions concentrated on the primary research questions in the study. Lastly, concluding comments were used to thank participants and reiterate the confidentiality of their responses. 
Arab World English Journal (AWEJ) 2nd Special Issue on Covid 19 Challenges January 2022

\section{Results and Discussion}

This part explores the responses provided by teachers and students during interviews in which they were asked about their experiences with online learning during the Pandemic. Mixtures of individual and group interviews were utilized to engage with a large sample of participants. Their responses were organized into key themes that were identified after a careful analysis of learners' responses and the findings of a comprehensive literature review that was conducted on the issue-

\section{i. Benefits Associated with the Shift to Online Lessons-}

As evident from the analysis, most students stated that they benefited from online learning to support their writing skills during the pandemic. Some of the students' responses are as follows;

Student A: I saw that my writing skills have improved, so I think after the last term, I saw the difference between my writing skills before one year and now.

Student B: Yes, I liked it. It positively affects my writing development.

It appears as though the resources available to students through the Internet, such as mind mapping software, played a major factor in their enjoyment of the experience, as they could use tools and applications to support their writing.

Student C: In my opinion, yes, I can do that because I learned many skills that help in simple writing, such as using the mind map, writing the introduction, the body of the paragraph and the conclusion in addition to the basics of writing.

Student D: Ok, In the past, I was using Google translate, but it was wrong because it gets the Arabic forms, but now after the teacher said that Google translate is not always right and probably is wrong, so I started to use my way in writing an email or essay or anything, and the mind map is helpful to improve writing skills.

While the teacher participant group identified several benefits, they appear to be dependent on learner motivation. Teachers felt that a great deal could be accomplished through online lessons, as they could quickly provide learners with activities and worksheets that challenged them and encouraged progress. However, they noted that this was only the case for motivated learners and that this new online format required a significant level of discipline and commitment.

In addition, according to Teacher B: In the online lectures, students could see different writing samples that helped them understand the organization of different writing formats. I could also give them feedback on their writing activities to improve their mistakes and improve their writing skills.

Interestingly, while the teachers felt it was more challenging to get engage students, student responses suggest the opposite. Several students stated that they felt more comfortable voicing their opinions and sharing with their peers during online lessons, claiming that they often felt shy or reluctant when in a physical classroom. One especially pleased student stated the following:

Student C: This experience made me develop my speaking skills. 
Additionally, learners felt that they benefited from the flexibility offered by online learning and claimed that this allowed them to take their time working through materials and worksheets.

Student E: I will be more responsible about my lectures and attend all my classes on time without waiting for anyone to tell me or encourage me because it is online, so it is easier to direct myself.

\section{ii. The Internet as a Tool for Learning Support-}

Both groups felt significant benefits associated with online learning, mainly when it came to the available resources on the Internet to support learners. For example, one teacher respondent noted that they felt it was beneficial for the learners to access search engines such as Google while completing their projects and assignments. They argued that this helped learners quickly answer their questions instead of waiting for an instructor to help them. When asked to describe how they use online resources in class, one teacher stated:

Teacher B: I can give them online assignments and other writing activities through different features on blackboard like discussion, forum, etc.

Many of the students agreed with this sentiment, with the majority claiming that they felt their writing improved through activities and assignments that were distributed online. When asked about how they can improve their experience, several students responded with complaints regarding the high price of textbooks and other school-related fees. Although this brings up the potential for online resources to help mitigate this problem, several students claimed that access to audio resources or electronic textbooks could be one way to alleviate this burden. This is an exciting proposition, although it is likely that universities will be unwilling to sacrifice the revenue generated from textbook sales. When asked about how teachers could better support learners, one student responded in the following way:

Student F: The college can give all the students the books and materials for free.

\section{iii. Challenges Regarding the Shift to Online Lessons-}

The two participant groups were able to identify a number of different challenges associated with the sudden movement to an online learning platform. For the teachers, it appeared as though learner motivation was a significant issue, with one teacher stating the following:

"It is mainly related to the students themselves. But, unfortunately, the students usually look for the easiest ways to get the marks."

The teacher explained that she believed that many students failed to attend lessons or participate in discussions and even suggested that many were using the Internet to find answers and complete their worksheets. This phenomenon is well supported in academic literature, as Spaulding indicates that learners are more likely to plagiarize in online formats (Spaulding, 2009).

Teacher B: Sometimes, they will copy and paste from each other or copy and paste from the Internet that also a challenge according to the writing.

Another teacher was more reflective when asked about their difficulties with the transition, claiming that they found it challenging to keep all the learners engaged throughout the 
Arab World English Journal (AWEJ) 2nd Special Issue on Covid 19 Challenges January 2022

lesson. The teacher elaborated that while they could maximize student talk time during in-person lessons through group activities and discussions, many of these techniques were no longer possible with the online platform. Finally, there was a particularly frustrated teacher who voiced their concern in the following way:

Teacher C: I want them to speak so that they can have confidence in speaking English. So even if they attend, they do not wish to participate, and also, many students claim that they have a technical issue.

One more teacher felt that allowing students to submit and resubmit their writing online created a significant amount of additional marking, causing them to put in additional hours at work. The teacher explained this by saying that students would now quickly address their comments and resubmit materials, which meant that the teacher would effectively have to mark the writing twice in a short period. Finally, one teacher discussed how they used the online format for assigning and grading student work while the students could not hand over their handwritten scripts to their teachers.

Teacher D: Those good students are responding, and the weakest students or unwilling students are not responding. So I could not get them physically as I could in the class. However, in the online setting, we could not reach them physically.

\section{iv. Suggestions Regarding the Shift to Online Lessons-}

Interestingly, the difficulties identified by the student group were mostly targeted towards external factors in their environment and issues with teacher availability. For example, one student felt that it took too long for their professor to respond to emails and questions, with another agreed that teachers were not as available during periods of online learning. This frustration can be seen in the following student response:

Student B: Sometimes, I receive feedback from my teacher, but I do not receive any feedback most of the time.

Additionally, problems with the technology needed were an issue, with a number of students claiming that Wi-Fi connectivity problems impacted their learning. This directly impacted their motivation to participate in group projects, stated one student, as conducting meetings or discussions through online methods was difficult to coordinate successfully. This suggests that if the infrastructure for internet technology is improved in the region the students live, they may find online learning more interactive and efficient than it currently is. One student made their frustrations clear in the following way:

Student D- All the time, the Internet is not stable; it is on and off many times during classes.

\section{Conclusion}

In conclusion, it appears as though both teachers and students feel that the shift to online learning was positive overall. The increased flexibility that comes with distance education was welcomed by students, who thought that it was a preferable alternative to traditional in-person classes and activities. Similarly, teachers were able to identify several positive aspects of the new approach and acknowledged that there was no drop in educational quality observed due to the transition. That said, there were concerned voices by both sides. Teachers felt that motivation and accountability were key issues, while students commented on slow teacher response times 
Arab World English Journal (AWEJ) 2nd Special Issue on Covid 19 Challenges January 2022

and barriers related to internet connectivity. Overall, the interviews indicate that if adjustments are made to improve current practice, online learning may be preferable to the traditional models.

Therefore, this study highlighted that while learning in the traditional classroom or a virtual classroom or using the virtual learning approaches, academic writing skills meet their expectations and needs in and outside the classroom. Saudi EFL learners have many problems and challenges in Academic writing skills, while the students were taught all the skills online, including writing skills during the Pandemic.

\begin{abstract}
About the Authors
Hebah Asaad Hamza Sheerah is currently an assistant professor of TESOL at the Department of English, Applied College for Girls, King Khalid University, Abha, Saudi Arabia since 2019. In October 2018, she got a Ph. D. degree from Reading University, the UK. She previously worked in Taiba University, Saudi Arabia for four years. Her areas of interest include blended learning, language \& education, teaching \& learning, curriculum development, and collaborative learning. She has participated in many international conferences. https://orcid.org/0000-0002$\underline{7775-4615}$
\end{abstract}

Meenakshi Sharma Yadav is an assistant professor of linguistics at the English Department, Applied College for Girls, King Khalid University, Abha, Saudi Arabia. She did her M. Phil. in ELT from the Banasthali Vidyapith, and TEFL from Org.uk, London. Dr. Meenakshi holds a $\mathrm{Ph}$. D. in linguistics from the University of Rajasthan. Her research areas are linguistics and literary criticism. https://orcid.org/0000-0001-7962-3267

May Ali Elzein Fadl Allah is a lecturer at the English department, King Khalid University. She holds an MA in ELT from the Khartoum University, and Ph. D. in applied linguistics from the Sudan University of Science and Technology, Sudan. Her research area is applied linguistics. https://orcid.org/0000-0003-3836-171X

Ghazwa Jalal Abdin is a lecturer of English at the English Department at King Khalid University. Ghazwa holds a Diploma in general linguistics and an M.A. in applied linguistics from Sheffield University in UK. Ghazwa's research is related to language teaching in higher education. https://orcid.org/0000-0002-5549-4189

\title{
References:
}

Remuzzi, A. Remuzzi, A. (2020). COVID-19 and Italy: What next? Lancet, 395,1225-1228. https://DOI.org/10.1016/S0140-6736(20)30627-9

Aghajani, M. \& Adloo, M. (2018). The Effect of Online Cooperative Learning on Students' Writing Skills and Attitudes through Telegram Application. International Journal of Instruction. 11. 433448. https://DOI.org/10.12973/iji.2018.11330a

Al Lily, A. E., Ismail, A. F., Abunasser, F. M., \& Alqahtani A, R. H. (2020). Distance education as a response to pandemics: Coronavirus and Arab culture. Technology in society, 63, 101317. https://DOI.org/10.1016/j.techsoc.2020.101317

Lahuerta, A. (2020) Analysis of Accuracy in the Writing of EFL Students Enrolled on CLIL and nonCLIL Programmes: The Impact of Grade and Gender, The Language Learning Journal, 48:2, 121-132. https://DOI.org/10.1080/09571736.2017.1303745 
Arab World English Journal (AWEJ) 2nd Special Issue on Covid 19 Challenges January 2022

Ababneh, I. (2017). Analysis of Written English: The Case of Female University Students in Saudi Arabia. International Journal of Social Science Studies, 5, (4) 1-5.

Ahmed, F. E. Y. \&. Elnour, I. A. H. (2018). Investigating Errors Committed by Saudi EFL University Students in Paragraph Writing A case study of College of Science \& Arts, Tanumah, King Khalid University.

Alfaqiri, M. (2018). English Second Language Writing Difficulties and Challenges Among Saudi Arabian Language Learners. Journal for the Study of English Linguistics, 6(1).

Alfehaid, A. (2019). Online English language learning activities and academic achievement: Experiences of first year students and their teachers. Pertanika Journal of Social Sciences \& Humanities, 27(2).

Aghajani, M., \& Adloo, M. (2018). The Effect of Online Cooperative Learning on Students' Writing Skills and Attitudes through Telegram Application. International Journal of Instruction, 11(3), 433-448.

Agung, A. S. N., Surtikanti, M. W., \& Quinones, C. A. (2020). Students' Perception of Online Learning during COVID-19 Pandemic: A Case Study on the English Students of STKIP Pamane Talino. SOSHUM: Jurnal Sosial Dan Humaniora, 10(2), 225-235.

Alharbi, M. A. (2019). Saudi Arabia EFL University Students' Voice on Challenges and Solution in Learning Academic Writing. Indonesian Journal of Applied Linguistics, 8 (3), 577-588. https://DOI.org/10.17509/ijal.v8i3.15276

Alharbi, N. S. M. (2017). An investigation into the academic writing: Difficulties of Saudi Postgraduate Students. Doctoral Thesis. University of Exeter. http://hdl.handle.net/10871/33113, AlharbiN.pdf (PDF, 5.850Mb).

Al-Hattami, A., \& Al-Ahdal, A. A. M. H. (2020). Detecting Language Disorders and Anxiety among Young Learners: Remediation Options in the Current Educational Paradigm. Asian EFL Journal, 27 (44), 97-115.

Alhujaylan, H. (2019). An Assessment of the Effectiveness of CALL in Teaching English Language Writing Skills in Saudi Arabia. Arab World English Journal (AWEJ) Special Issue on CALL 518 27. https://dx.doi.org/10.24093/awej/call5.2

Ali, M., J. K. (2017). Blackboard as a Motivator for Saudi EFL Students: A Psycholinguistic Study. International Journal of English Linguistics 7(5):144. https://dx.doi.org/10.5539/ijel. v7n5p144.

Almaiah, M.A., Al-Khasawneh, A., \& Althunibat, A. (2020). Exploring the critical challenges and factors influencing the E-learning system usage during COVID-19 pandemic. Educ Inf Technol 25, 5261-5280. https://doi.org/10.1007/s10639-020-10219-y

Almekhlafy, S.S.A. (2020). Online learning of English language courses via blackboard at Saudi universities in the era of COVID-19: perception and use. PSU Research Review, Vol. ahead-ofprint No. ahead-of-print. https://doi.org/10.1108/PRR-08-2020-0026

Almusharraf, N. M. (2019). Learner Autonomy and Vocabulary Development for Saudi University Female EFL Learners: Students' Perspectives. International Journal of Linguistics, 11(1). https://doi.org/10.5296/ijl.v11i1.13782

Al-Nofaie, H. (2020). Saudi University Students' Perceptions towards Virtual Education During Covid19 Pandemic: A Case Study of Language Learning via Blackboard. ArabWorldEnglishJournal,11(3)420. https://dx.doi.org/10.24093/awej/vol11no3.1

Alqahtani, N., Innab, A., \& Bahari, G. (2020). Virtual Education During COVID-19: Exploring Factors Associated with E-Learning Satisfaction Among Saudi Nursing Students. Nurse educator, 
Arab World English Journal (AWEJ) 2nd Special Issue on Covid 19 Challenges January 2022

10.1097/NNE.0000000000000954. The Saudi MOE Leading Efforts to Combat Coronavirus Pandemic (COVID-19).

Alrabai, F. (2017). Saudi EFL Teachers' Perspectives on Learner Autonomy. International Journal of Linguistics, 9(5). https://doi.org/10.5296/ijl.v9i5.11918

Alrabai, Fakieh (2018). Learning English in Saudi Arabia. English as a Foreign Language in Saudi Arabia: New Insights into Teaching and Learning English Publisher. Book. Routledge Learning English in Saudi Arabia. https://doi.org/10.4324/9781315688466-5

Al Shahrani, H. M. (2018). Mother Tongue Interference: A study of Inter Lingual Errors in The Written Performance of the EFL Preparatory Year Female Students at Al-Baha University in Saudi Arabia. Journal of Humanities and Social Sciences (Arab Journal of Sciences\& Research Publishing), 2(2), 118-135. https://doi.org/10.26389/AJSRP.H260118

Alshakhi, A. (2019). Assessing the Writing Assessment. The Perception of Saudi Graduate EFL Learners: A Case Study. Arab World English Journal, Special Issue 1: Application of Global ELT Practices in Saudi Arabia. 87-102. DOI: https://dx.doi.org/10.24093/awej/elt1.7

Ashraf, T. A. (2018). Teaching English as a Foreign Language in Saudi Arabia: Struggles and Strategies. International Journal of English Language Education, 6(1), 133-154. https://DOI.org/10.5296/ijele.v6i1.13148

Al Tameemy, F. A., Alrefaee, Y., \& Alalwi, F. S., (2020) Using blackboard as a tool of e-assessment in testing writing skill in Saudi Arabia. The Asian ESP Journal (16) 6, 183-202.

Altheneyan, A. \& Boayrid, N. F. (2019). Writing Errors Among Arab EFL Learners: A Review of Literature. International Journal of Linguistics, 11 (5), 319-329. DOI: https://DOI.org/10.5296/ijl.v11i5.15294

Alzankawi, M. (2017). Kuwaiti undergraduate problems with cohesion in EFL Writing. In Proceedings of International Academic Conferences (No. 5807931). International Institute of Social and Economic Sciences.

Alzaidi, G.F. (2017). The Effect of Memory Strategy Training on Vocabulary Learning by EFL Female Students of the College of Languages and Translation: An Experimental Stud. Department of English at the College of Arts, King Saud University (Master's Thesis). Retrieved from (Arab World English Journal Database. (ID Number: 205, June 2018). https://dx.DOI.org/10.24093/awej/th.205

Alzamil, A. (2019). The Effects of the Use of First Language on Learning English as a Second Language: Attitudes of Arabic EFL Learners. Arab World English Journal, 10 (3) 192201.https://dx.DOI.org/10.24093/awej/vol10no3.13

Angelino, L. M., Williams, F. K., \& Natvig, D. (2007). Strategies to engage online students and reduce attrition rates. Journal of Educators Online, 4(2),2.

Bahari, A., \& Salimi, M. (2021). Challenges and Affordances of Developing Receptive and Productive Skills via Technology-Based Instruction. CALL-EJ 22(1):22-52.

Bakkar, B. B. (2019). The Writing Center's Role in the Academic Life of an English Foreign Language Student from an Instructor's Perspective. Arab World English Journal, 10 (3)32-42. https://dx.doi.org/10.24093/awej/vol10no3.3

Basabrin, A. (2019). Exploring EFL Instructors and Students Perceptions of Written Corrective Feedback on Blackboard Platform: A Case Study. Arab World English Journal, Special Issue 1: Application of Global ELT Practices in Saudi Arabia. 179-192. https://dx.DOI.org/10.24093/awej/elt1.13 
Arab World English Journal (AWEJ) 2nd Special Issue on Covid 19 Challenges January 2022

Belabes, Abderrazak (2018). Teaching Entrepreneurial Finance in Saudi Arabia Teaching Entrepreneurial Finance in Saudi Arabia: An Overview and Prospects. Kyoto Bulletin of Islamic Area Studies, 11, 95-108.

Bergdahl, N., \& Nouri, J. (2020). Covid-19 and crisis-prompted distance education in Sweden. Technology, Knowledge and Learning, 1-17.

Bostanci, H. B., \& Çavușoğlu, Ç. (2018). Pen-and-paper or online? An academic writing course to teacher-trainees. Cogent Education, 5(1), 1482606.

Coman, C.; Țîru, L. G.; Meseșan-Schmitz, L.; Stanciu, C. \& Bularca, M. C. (2020). Online Teaching and Learning in Higher Education during the Coronavirus Pandemic: Students' Perspective. Sustainability 12, no. 24: 10367. https://DOI.org/10.3390/su122410367

Daniel, S. J. (2020). Education and the COVID-19 pandemic. Prospects (Paris): 1-6. PMCID: PMC7167396. https://DOI.org/10.1007/s11125-020-09464-3

Darling-Aduana, J., \& Heinrich, C. J. (2018). The role of teacher capacity and instructional practice in the integration of educational technology for emergent bilingual students. Computers \& Education, 126, 417-432.

Dhawan S. (2020). Online Learning: A Panacea in the Time of COVID-19 Crisis. Journal of Educational Technology Systems, 0047239520934018. https://DOI.org/10.1177/0047239520934018

EdSource. (2020). Coronavirus: Highlighting strategies for student success. Retrieved fromhttps://edsource.org/topic/coronavirus.

Elyas, T., \& Badawood, O. (2017). English Language Educational Policy in Saudi Arabia Post 21st Century: Enacted Curriculum, Identity, and Modernisation: A Critical Discourse Analysis Approach, 3(3). Retrieve from http://preserve.lehigh.edu/fire/vol3/iss3/3

Faradhibah, R. N. (2017). Analyzing Students' Difficulties in Maintaining their Coherence and Cohesion in Writing Process. ETERNAL (English, Teaching, Learning and Research Journal). 3(2) 183 194.

Farooq,U. \& Soomro, A.F. (2018). English Language Teaching and Cultural Implications in Saudi Arabia. International Journal of English Linguistics, 8 (3), 177-183. https://doi.org/:10.5539/ijel. v8n3p177

Ferri, F., Grifoni, P. \& Guzzo, T. (2020). Online Learning and Emergency Remote Teaching: Opportunities and Challenges in Emergency Situations. Societies, 10, 86. https://DOI.org/10.3390/soc10040086

Gelles, L. A., Lord, S. M., Hoople, G. D., Chen, D. A., \& Mejia, J. A. (2020). Compassionate flexibility and self-discipline: Student adaptation to emergency remote teaching in an integrated engineering energy course during COVID-19. Education Sciences, 10(11), 304.

Gharehblagh, N. M., \& Nasri, N. (2020). Developing EFL Elementary Learners' Writing Skills through Mobile-Assisted Language Learning (MALL). Teaching English with Technology, 20(1), 104121.

Hafiz, M. S., Omar, A. M. A., Gul Sher K. U. R. M (2018). Analysis of Syntactic Errors in English Writing: A Case Study of Jazan University Preparatory Year Students. Journal of Education and Practice, 9 (11), 113-120.

Hassounah, M., Raheel, H., \& Alhefzi, M. (2020). Digital Response During the COVID-19 Pandemic in Saudi Arabia. Journal of medical Internet research, 22(9), e19338. https://DOI.org/10.2196/19338 
Arab World English Journal (AWEJ) 2nd Special Issue on Covid 19 Challenges January 2022

Honey, H. (2020). Teachers as Writers: A descriptive case study of my observations of English teachers in the middle school classroom. SHAREOK: advancing Oklahoma scholarship, research and institutional memory. https://hdl.handle.net/11244/325291

Hussein, N. O. \& Elttayef, A. I. (2017). Arab Learners' Problems in Learning English Language: A Teacher Perspective. Research Journal of Finance and Accounting, 8 (23).

Hussain, I., Saeed, R. \& Syed, A. (2020). A Study on Effectiveness of Online Learning System during COVID-19 in Sargodha. International Journal of Language and Literary Studies. 2. 122-137. https://doi.org/10.36892/ijlls.v2i4.404

Ionescu, C. A.; Paschia, L.; Gudanescu N. N. L.; Stanescu, S. G.; Neacsu S. V. M.; Coman, M. D.; Uzlau, M. C. (2020). Sustainability Analysis of the E-Learning Education System during Pandemic Period-COVID-19 in Romania. Sustainability 12, no. 21: 9030. https://doi.org/10.3390/su12219030

Kaden, U. (2020). COVID-19 school closure-related changes to the professional life of a K-12 teachers. Education Sciences, 10(6), 165.

Karata, T. K. \& Tuncer, H. (2020). Sustaining Language Skills Development of Pre-Service EFL Teachers despite the COVID-19 Interruption: A Case of Emergency Distance Education. Sustainability, 12(19), 8188; https://DOI.org/10.3390/su12198188.

Khalil, Hanan \& Ebner, Martin (2017). Using Electronic Communication Tools in Online Group Activities to Develop Collaborative Learning Skills. Universal Journal of Educational Research, 5(4), 529-536. http://www.hrpub.org https://DOI.org/10.13189/ujer.2017.050401

Khalil, R., Mansour, A.E., Fadda, W.A. et.al. (2020). The sudden transition to synchronized online learning during the COVID-19 pandemic in Saudi Arabia: a qualitative study exploring medical students' perspectives. BMC Med Educ 20, 285. https://doi.org/10.1186/s12909-020-02208-z

Khan, Waquar Ahmad (2020). Compulsory English Language Teaching in Taibah University at Undergraduate Level: Problems and Challenges. Journal for the Study of English Linguistics, 9 (1). https://DOI.org/10.5296/jsel.v9i1.17848

Khatter, S. (2019). An Analysis of the Most Common Essay Writing Errors among EFL Saudi Female Learners (Majmaah University). Arab World English Journal, 10 (3) 364-381. https://dx.DOI.org/10.24093/awej/vol10no3.26

Mansory, M. (2019). Exploring Teachers' Beliefs and Practices on the Use of the Mother Tongue as a Mediational Tool in a Saudi EFL Classroom. Arab World English Journal, Special Issue 1: Application of Global ELT Practices in Saudi Arabia. 72-86. https://dx.doi.org/10.24093/awej/elt1.6.

Martinez, J. (2020). Take this pandemic moment to improve education. Edu Source. Retrieved from https://edsource.org/2020/take-this-pandemic-moment-to-improve-education/633500

McDonough, K., \& Crawford, W. J. (2020). Identifying effective writing tasks for use in EFL write-tolearn language contexts. Language Learning Journal, 48(4), 469-480. https://doi.org/10.1080/09571736.2018.1465990.

Mishra, L., Gupta, T., and Shree, A. (2020). Online teaching-learning in higher education during lockdown period of COVID-19 pandemic. International Journal of Educational Research Open, 1(2020) 100012. https://doi.org/10.1016/j.ijedro.2020.100012

Mpungose, C.B. (2020). Emergent transition from face-to-face to online learning in a South African University in the context of the Coronavirus pandemic. Humanit Soc Sci Commun 7, 113. https://doi.org/10.1057/s41599-020-00603-X. 
Arab World English Journal (AWEJ) 2nd Special Issue on Covid 19 Challenges January 2022

Mudawy, A. M. Ahmed \& Mousa, A. A. E. Mousa (2017). Academic Writing among Saudi University Students: Problems and Solutions A Case Study: English Language Students, Department of English, College of Education in Zulfi- Majmaah University. International Journal of Science and Research, 6 (5). https://doi.org/10.21275/ART20172929

Mujtaba A., Safia (2019). The Role of Mobile Phones as Effective Tools for Language Learning by Libyan EFL Learners. Journal of English Education and Linguistics Studies, (2), 135-163. https://doi.org/10.30762/jeels.v 6i2.1234

Mutambik, Ibrahim (2018). The Role of E-learning in Studying English as a Foreign Language in Saudi Arabia: Students' and Teachers' Perspectives. English Language Teaching; 11 (5), 74-83. https://doi.org/10.5539/elt.v11n5p74

Muthuprasad, T., Aiswarya, S., Aditya, K. S., \& Jha, G. K. (2021). Students' perception and preference for online education in India during COVID-19 pandemic. Social Sciences \& Humanities Open, 3(1), 100101.

Niittylahti, S., Annala, J., \& Mäkinen, M. (2021). Student engagement profiles in vocational education and training: a longitudinal study. Journal of Vocational Education \& Training, 1-19.

Purpura, D. J., Napoli, A. R., Wehrspann, E. A., \& Gold, Z. S. (2017). Causal connections between mathematical language and mathematical knowledge: A dialogic reading intervention. Journal of Research on Educational Effectiveness, 10(1), 116-137. https://doi.org/10.1080/19345747.2016.1204639

Putri, R. S., Purwanto, A., Pramono, R., Asbari, M., Wijayanti, L. M., \& Hyun, C. C. $\quad$ (2020). Impact of the COVID-19 pandemic on online home learning: An explorative study of primary schools in Indonesia. International Journal of Advanced Science and Technology, 29(05), 4809-4818.

Radianti, J., Majchrzak, T.A., Fromm., Wohlgenannt, I. (2020). A systematic review of immersive virtual reality applications for higher education: Design elements, lessons learned, and research agenda, Computers \& Education, 147, ISSN 0360-1315, https://doi.org/10.1016/j.compedu.2019.103778.

Rieley J. B. (2020). Corona Virus and its impact on higher education. Research Gate.

Rapanta, C., Botturi, L., Goodyear, P. et al. (2020). Online University Teaching During and After the Covid-19 Crisis: Refocusing Teacher Presence and Learning Activity. Postdigit Sci Educ 2, $923-$ 945. https://doi.org/10.1007/s42438-020-00155-y

Sadighi, F., \& Dastpak, M. (2017). The Sources of Foreign Language Speaking Anxiety of Iranian English Language Learners. International Journal of Education and Literacy Studies, 5(4), 111115. http://dx.doi.org/10.7575/aiac.ijels. v.5n.4p.111

Samuels, B. \& Garbati, J. (2018). Mastering Academic Writing. SAGE. ISBN 978-1-5264-5506-2.

Schulten, K. (2020). Coronavirus resources: Teaching, learning and thinking critically. The New York Times. Retrieved from file:///D:/COVID/Coronavirus\%20Resources\%20Teaching,\%20Learning\%20and\%20Thinking\% 20Critically\%20-\%20The\%20New\%20York\%20Times.html

Selvaraj, M. \& Abdul A. A. (2019). Systematic Review: Approaches in Teaching Writing Skill in ESL Classrooms. International Journal of Academic Research in Progressive Education and Development. 8. 2226-6348. https://doi.org/10.6007/IJARPED/v8-i4/6564

Serdyukov, P. (2017). Innovation in education: what works, what doesn't, and what to do about it?. Journal of Research in Innovative Teaching \& Learning, 10(1), 4-33. https://doiI.org/10.1108/JRIT-10-2016-0007 
Arab World English Journal (AWEJ) 2nd Special Issue on Covid 19 Challenges January 2022

Sheerah, H. A. H. (2020). Using Blended Learning to Support the Teaching of English as a Foreign Language. Arab World English Journal (AWEJ), Special Issue on CALL (6).191- 211. https://dx.doi.org/10.24093/awej/call6.13.

Spaulding M., (2009). Perceptions of Academic Honesty in Online vs Face-to-Face Classrooms. The University of Tennessee - Martin. Journal of Interactive Online Learning www.ncolr.org/jiol, 8 (3). ISSN: 1541-4914.

Tejedor, S.; Cervi, L.; Pérez-Escoda, A.; Jumbo, F.T. (2020). Digital Literacy and Higher Education during COVID-19 Lockdown: Spain, Italy, and Ecuador. Publications, 8(48). https:// doi.org/10.3390/publications8040048

Uskov V.L., Bakken J.P., Gayke K., Jose D., Uskova M.F., \& Devaguptapu S.S. (2019). Smart University: A Validation of "Smartness Features-Main Components" Matrix by Real-World Examples and Best Practices from Universities Worldwide. In: Uskov V., Howlett R., Jain L. (eds) Smart Education and e-Learning 2019. Smart Innovation, Systems and Technologies, 144. Springer, Singapore. https:// doi.org/10.1007/978-981-13-8260-4 1

Weber A.S. (2018). Saudi Arabia. In: Weber A., Hamlaoui S. (eds) E-Learning in the Middle East and North Africa (MENA) Region. Springer, Cham. https://doi.org/10.1007/978-3-319-68999-9 16

Tuma, F., Nassar, A. K., Kamel, M. K., Knowlton, L. M., \& Jawad, N. K. (2021). Students and faculty perception of distance medical education outcomes in resource-constrained system during COVID-19 pandemic. A cross-sectional study. Annals of Medicine and Surgery, 62, 377-382. https://doi.org/10.1016/j.amsu.2021.01.073

Woodrich, M., \& Fan, Y. (2017). Google Docs as a tool for collaborative writing in the middle school classroom. Journal of Information Technology Education: Research, 16(2), 391-410.

Yadav, M. S. (2020). Role of Social Media in English Language Learning to the Adult Learners. International Journal of Linguistics, Literature and Translation, 4(1), 238-247. https://doi.org/10.32996/ijllt.2021.4.1.25

Yadav, M. S., Yadav, M. K. (2020). Role of the Transformational Generative Grammar and other Language Learning Theories in English Language Teaching. Electronic Research Journal of Social Sciences \& Humanities, 2(1) 142-153.

Yousuf, A. F. (2019). Errors of Unity and Coherence in Saudi Arabian EFL University Students' Written Paragraph - A Case Study of College of Science \& Arts, Tanumah, King Khalid University, Kingdom of Saudi Arabia. European Journal of English Language Teaching, 4 (3), 125-155.

\section{Web Sources}

1. https://www.who.int/news/item/27-04-2020-who-timeline-covid-19

2. https://en.wikipedia.org/wiki/COVID-19_pandemic_in_Saudi_Arabia

3. https://en.wikipedia.org/wiki/National_Center_for_e-Learning

4. https://www.arabnews.com/node/1638606/saudi-arabia,2020 Saudi Arabia closes schools over coronavirus concerns.

5. https://www.englishexplorer.com.sg/the-influence-of-culture-in-learning-english-language/ The Influence of Culture in Learning English Language

6. https://www.arabnews.com/node/1773401/saudi-arabia,2020 KSA tagged as 'one of the fastest countries' to respond to educational emergencies. 
Arab World English Journal (AWEJ) 2nd Special Issue on Covid 19 Challenges January 2022

Sheerah, Yadav, Allah, \& Abdin

7. https://saudigazette.com.sa/article/24861 Status and functions of English in Saudi Arabia, December 11, 2012

8. School students in Saudi Arabia 2013-2017Published by Statista Research Department, Dec 8, 2020.

9. https://iite.unesco.org/wp-content/uploads/2020/10/The-Saudi-MOE-Leading-Efforts-toCombat-Coronavirus-Pandemic-COVID-19.pdf

10. Magrath, Douglas (2020). Understanding the structure of Arabic for ESL teachers. https://exclusive.multibriefs.com/content/understanding-the-structure-of-arabic-for-eslteachers/education

11. https://www.learndash.com/4-basic-language-skills-to-cover-in-an-online-course/

12. https://essaywritingserviceuk.co.uk/advice-and-guidance/thematic-analysis

\section{Appendices}

\section{A. Teachers' Questionnaire:}

Main research questions:

1- What are EIP students' and teachers' perceptions concerning the benefits of emergency of online learning on writing course during COVID-19 pandemic?

2- What are EIP students' and teachers' perceptions concerning the challenges of emergency of online learning on writing course during COVID-19 pandemic?

3- What are EIP students' and teachers' suggestions on how online program could be useful to develop English language skills?

\section{Interview Questions}

\section{Benefits:}

1. What do you think about the experience of online teaching and learning academic writing skills during the COVID-19 Pandemic?

2. Regarding to academic writing, how does online learning on IEP promote students' writing skills?

3. In your opinion, did online learning positively affect the students' academic writing skills? How?

4. How do you manage online writing activities?

Challenges:

5. What do you think are the major challenges of emergency online learning IEP on writing course during COVID-19?

6. Did you face any complications in online teaching? Examples?

7. What did you do to make the course useful for the students?

8. What other challenges have you faced while teaching academic writing online? Suggestions:

9. What factors should teachers consider to make online learning IEP on writing course more effective?

10. What else should be done to improve online learning IEP on writing course in the future?

11. Is there anything you would like to add? (Do you have any other comments?)

B. Students' Questionnaire

\section{Interview Question}

- What do you think about the experience of online learning academic writing skills during the COVID-19 Pandemic?

Benefits 
1. Regarding academic writing skills, having completed this course, do you feel that you are able to write a piece of academic work in English?

2. In your opinion, did online learning positively affect your academic writing skills? How?

3. Did you get any feedback from your lecturer concerning your writing?

4. What is the main general development you made from online learning in relation to your English skills?

5. Did you learn to be a self-directed student? Examples?

6. Did you experience group working, interactions in blended learning?

7. In which skill?

\section{Challenges}

1. What are the major challenges or difficulties you encounter during the emergency online learning IEP on Academic writing during COVID 19 pandemic?

2. To what extent did these challenges affect your learning and performance?

3. Did you face any complications when participating in online learning? Examples?

4. Did you face any technical difficulties during online classes?

5. What are other challenges or difficulties have you faced during the online writing course? Suggestions

1. How can online learning IEP be useful to develop your English language writing skills?

2. In your opinion, what makes online learning IEP on writing courses more interesting and enjoyable?

3. How can your teacher/college support you further?

4. Do you have any additional suggestions or comments that you would like to add? 